\title{
Maximizing the Efficiency of Greenhouse Gas Related Consumer Policy
}

\author{
Mária Csutora • Ágnes Zsóka
}

Received: 2 February 2010 / Accepted: 26 October 2010 /

Published online: 19 November 2010

(C) Springer Science+Business Media, LLC. 2010

\begin{abstract}
Consumer policy approaches regarding green products and solutions can be differentiated by their main focus. "Green positioning" is basically targeted at environmentally aware consumers, while "efficiency-focused positioning" concentrates on the efficiency gain of the product or solution, targeting the whole society, regardless of consumers' environmental awareness. The paper argues that the scope and total environmental benefit can be increased if green products or solutions are promoted in different ways, not only as "green" but also based on other arguments (like cost-efficiency, return on investment, etc.). The paper suggests a model for improving the efficiency of greenhouse gas (GHG)-related consumer policy. Based on the marginal social cost curve and the marginal private cost curve, different (green, yellow, and red) zones of action are identified. GHG mitigation options chosen from those zones are then evaluated with the help of profiling method, addressing the barriers to implementation. Profiling may help design an implementation strategy for the selected options and make consumer policy more effective and acceptable for mass market. Case study results show three different ways of positioning of GHG-related consumer policy in Hungary from 2000 and give practical examples of profiling, based on the latest marginal social cost curve and the contemporary energy saving policy of the state regarding the residential sector.
\end{abstract}

Keywords Green positioning $\cdot$ GHG emission $\cdot$ Marginal abatement costs $\cdot$ Marginal social costs $\cdot$ Consumer policy profile

M. Csutora • Á. Zsóka (凹)

Department of Environmental Economics and Technology, Institute of Environmental Science, Corvinus University of Budapest, Fővám tér 8, 1093 Budapest, Hungary

e-mail: agnes.zsoka@uni-corvinus.hu

M. Csutora

e-mail: maria.csutora@uni-corvinus.hu 


\section{Introduction}

Recently, a lot of efforts have been made to effectively change consumer behaviour towards sustainability. However, there is still a lot to do in some areas to achieve the desired and required results. Reducing the emission of greenhouse gases (GHGs) is one of those areas. The ongoing efforts of governments to establish and implement policies aiming at reducing negative environmental impacts are vital if we want to keep climate change under control in the future (see World Research Institute 2010). As the costs of necessary measures can be considerable, a number of economic analyses have been carried out during the last decade to explore which technologically feasible abatement options are able to realize the biggest emission reduction potential with the least social cost (Creyts et al. 2007; Stern 2008; ÜrgeVorsatz and Füle 1999). These studies suggest that there exist a number of options with both huge savings and "negative costs" that provide the possibility for win-win solutions. However, as some authors point out, organizations do not necessarily implement those options without external governmental support (Zilahy 2004). It is also true for individuals that they often do not transform their positive environmental attitudes into environmentally aware consumption habits (Nemcsicsné Zsóka 2005), or if they do, then their increasing consumption level may compensate or over-compensate the benefits gained by proenvironmental consumer behaviour.

The paper argues that consumer policy can be made more effective if these "gaps" are recognized and considered during the implementation process, implying that

- The focus of consumer policy shifts from just increasing the demand of environmentally aware customers for products positioned as "green" to widening the consumer basis to include uninterested consumers by focusing on efficiency and payback rather than on "greenness."

- Differences between marginal social and marginal private costs of abatement are considered when selecting from mitigation options to be promoted.

- Barriers to implementation are identified.

- Profiling of options is used for mapping relevant implementation barriers and for building up a strategy to overcome those barriers.

A case study of Hungarian GHG-related consumer policy illustrates the use of the assessment model in practice to evaluate consumer policy alternatives and their implementation from the point of view of market penetration and environmental impact.

\section{Green Positioning and Efficiency-Focused Positioning Approaches in Consumer Policy}

Consumer policy for products with small or significantly reduced environmental impact can be formulated either on the basis of green positioning or on traditional marketing tools highlighting efficiency. Both are relevant approaches in consumer policy and can result in the spreading of green products, but their target groups, reach, and argumentation are different.

- Green positioning of green products: The most important objective of environmentally oriented consumer policy is to find the most effective way to motivate people to change their consumer behaviour. The focus of the policy is on lifestyle change and the increase of environmental awareness. This approach basically targets consumers who are already "ex ante" environmentally aware or are at least open to new, green ideas and perceive the importance of lifestyle change. 
- Efficiency-focused positioning of green products: The key objective of this approach is to promote products with the least negative environmental impact and spread them in the whole society, independent of the environmental awareness of the target group. The argumentation is based on traditional marketing communication, where efficiency and payback are focal points. The radius of its reach is definitely wider and may give consumer policy the chance to raise environmental awareness "ex post" in the target group.

As the focus and argumentation of the two approaches are different, then problem perception and the outcome of consumer policy will also be different. The green positioning approach, aiming at lifestyle change, tries to promote appealing products and solutions which are in line with the motivations of individuals. It does not require too much sacrifice and can be used easily and effectively (Thøgersen 2005).

It seems evident that consumer choices are far from consistently rational and that there are several obstacles to pro-environmental choices, such as well-established habits, convenience, lack of information (Davies et al. 2002; Hofmeister-Tóth et al. 2010; Kollmuss and Agyeman 2002), low perceived consumer effectiveness (Ellen et al. 1991), and limited cognitive capacity to pay attention to time- and energy-demanding new solutions (Behr and Iyengar 1985, cited by Thøgersen 2005). Fliegenschnee and Schelakovsky (1998) claim that $80 \%$ of motives influencing people's environmental awareness (or the opposite) can be traced back to situational and internal (personal) factors. Increasing knowledge itself does not necessarily result in behavioural change (Davies et al. 2002; Kollmuss and Agyeman 2002), and even change of attitudes and values often seems insufficient of altering individual behaviour (Arbuthnott 2009). However, it may be necessary to change attitudes and values to encourage pro-environmental action, as well as socio-cultural factors such as social norms (Ajzen 1985; Widegren 1998), group identity (Bonaiuto et al. 1996), and interpersonal relationships (Jaeger et al. 1993) seem to significantly influence pro-environmental consumer behaviour.

Beyond internal motivation and the above-mentioned factors, external constraints also have to be removed in order to make sustainable lifestyle options available, practicable, and popular. The most important external constraints are lack of infrastructure (Hines et al. 1986), lack of contextual support (Stern 2000), poor quality pro-environmental solutions (e.g., public transport), insufficient supply or availability of labelled environment-friendly products, as well as deficiencies regarding well-established consumer culture, city layout, climate, etc. (Thøgersen 2005). Without a facilitating external framework for the desired behaviour, lifestyle change cannot be expected to happen nor will it last.

As sustainable consumption policies are becoming widespread, especially in the more developed countries, they provide fruitful ground for researchers to assess their effectiveness as well as their social, environmental, and economic impacts. Rubik et al. (2009) evaluated several innovative approaches of European sustainable consumption policies with regard to three important criteria: how these approaches and campaigns increase user awareness along the supply chain, whether they make sustainable consumption easy, and to what extent they contribute to the greening of markets. They used two databases, prepared by United Nations Environment Programme (UNEP) and United Nations Department of Economic and Social Affairs, on sustainable consumption policy initiatives and on consumption and productions patterns (see reference in Rubik et al. 2009). According to their findings,

- "the provision of information about alternatives to current unsustainable consumption patterns will, though important, most often not be sufficient to achieve a durable change in people's behaviour, 
- as individual consumption is an outcome of individual behaviours and collective practices, change will require intervention at both the individual and social (e.g. community) levels." (Rubik et al. 2009, p. 30).

One of the most important aspects in implementation of sustainable consumer policy is that the awareness that a sustainable consumption campaign aims to increase should be embedded and institutionalized (Rubik et al. 2009). Paavola (2007) calls for a change in institutions to resolve conflicts over environmental resources as an issue of social justice rather than a matter of efficiency. Burgess et al. (2003), Shove (2003), and Southerton et al. (2004) also describe the structural influence on people and the significance of social context in inspiring pro-environmental behaviour, while Spaargaren and Martens (2005) stress the importance of capacity for change when expecting individuals to behave in a more sustainable way. Few consumers behave $100 \%$ consistently green (or non-green), but they mix several patterns in their lifestyle where green behaviour elements are usually adopted only if they are made easy and are rewarded (see Marjainé Szerényi et al. 2009; Shove et al. 2007; Spaargaren 2000, 2003).

Several authors argue that environmental campaigns based on environmental awareness and aimed at lifestyle change have not been successful enough so far. Thøgersen and Crompton (2009) discuss the limitations of the spillover effects in environmental campaigning, stating that "simple and painless" lifestyle changes do not necessarily lead to more radical, more sustainable ones, at the individual level. The spillover effect can also be limited due to the fact that sustainable consumption campaigns often reach only people who are interested and committed anyway and that the nature of the campaigns hampers the widening of the scope for the public (see the Eco Teams campaign, assessed in GAP 2008). Voluntary actions are always limited by the fact that they are chosen by interested parties, and the added value needs to be thoroughly proven before evoking action. Robins and Roberts (2006) claim that environmental campaigns should focus on the community instead of individuals, as a "critical mass" has to be reached to make behaviour change apparent in the whole society.

In sum, the green positioning approach has the peculiar feature of addressing and reaching mainly consumers with already existing environmental awareness, and it does not really evoke behavioural change in non-interested consumers who are not open to environmental argumentation.

Hence, the efficiency-focused approach to consumer policy also has its relevance, as it aims to promote environmentally friendlier products with economic perspectives (cost savings, payback, etc.) instead of using an environmental argumentation. As a first step, it is important to know which products can provide the biggest efficiency gain. The environmental impacts of products and services are analysed in several studies relying on two different ways of calculation: the "bottom-up" and the "top-down" approaches. Appliers of the "bottom-up" approach first select a number of products which they think best represent a given expenditure category. Based on life-cycle assessment data for those products, they extrapolate for the total consumption of that specific expenditure category, estimating the total environmental impact relating to that category (Labouze et al. 2003; Tukker and Jansen 2006). The "top-down" approach uses input-output tables with environmental extensions, which are allocated to final expenditure categories (Moll et al. 2006; Weidema et al. 2006).

As data sources and methodologies are different, results are often criticized for producing hardly comparable outputs. However, Tukker and Jansen (2006) reviewed 11 studies - including both bottom-up and top-down approaches-focusing on the life-cycle 
impacts of total consumption at society level, as well as analysing the relative importance of different final consumption categories. They compared the results of the selected studies on the basis of Classification of Individual Consumption by Purpose final expenditure categories and came to the conclusion that the biggest environmental impacts are caused by a small number of product categories. According to the analysed studies, "food, housing and related energy use, and transport are in total responsible for some $70 \%$ or more of the total lifecycle impacts of all products and services used for final household and government consumption, whereas these categories are responsible for only $55 \%$ of the final expenditure" (Tukker and Jansen 2006, p. 175). Earlier, van Raaij and Verhallen (1983) stated that the residential sector was responsible for about $30 \%$ of the total energy demand in The Netherlands. Spreading energy saving methods is obviously an area where spectacular changes can be realized for the sake of the environment.

Again, the efficiency-focused approach addresses all consumers, regardless of their interest and awareness concerning environmental issues. The wide scale of utilizing the efficiency gain coming from green products can result in significant environmental benefit, especially in the case of products with the most reduced negative environmental impacts.

Figure 1 gives an overview of the two basic ways of reducing environmental impacts of consumption, illustrating the different features of the two consumer policy approaches discussed: either we can work on multiplying the number of green consumers or just make the products and services bought by non-green, uninterested mass consumers, environmentally friendly.

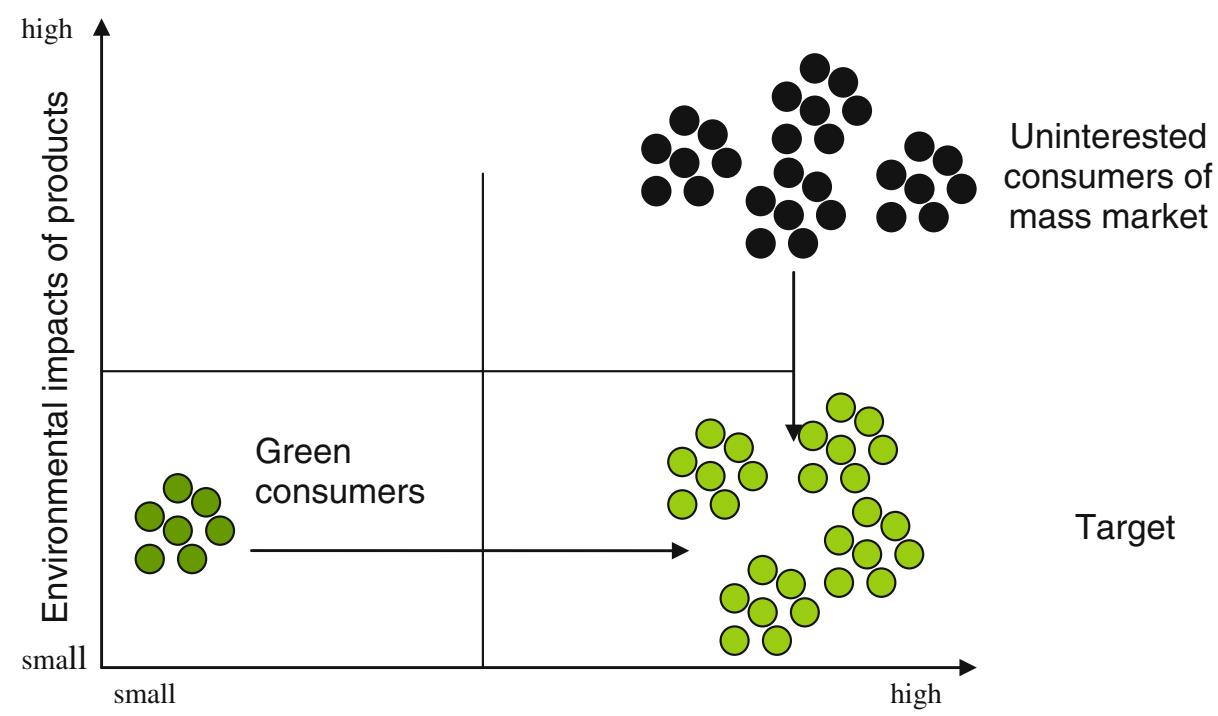

Share of consumers on the market

Fig. 1 Two basic ways of reducing environmental impacts of consumption. This figure was inspired-by analogy - by the "sustainable entrepreneurship theory" of Hockerts and Wüstenhagen (2009) about "emerging Davids" and "greening Goliaths." The approach demonstrates the phenomenon that at the beginning of a transformation process towards sustainability, new entrants (called "emerging Davids") are more likely to be sustainability pioneers (example, bio-shops). Well-established, big players of the market (called "greening Goliaths") follow "Davids" in greening and, although they often set less ambitious environmental and social goals, their established market presence may result in a broader reach. First version of the "Davids and Goliaths" model was made by Wüstenhagen (1998) 
The horizontal axis represents the market share of the given consumer group, while the vertical axis shows the environmental impacts of the purchased products. Regarding green consumers, it is assumed that the market products chosen by this group have relatively low environmental impacts (we may call them "green" products). However, not all consumers buying those products exert low impact on the environment. "Prestige greens" and "leading greens" (Peattie 1999) are characterized by a high consumption level, in spite of their "green" buying habits. "Cheaply greens" are those whose consumption results in relatively low environmental impacts. The market share of consumers buying green products is relatively small and, according to international surveys such as Eurobarometer 217 and 295, it does not seem to change much, even if reported environmental awareness is increasing (see European Commission 2005, 2008). "What has happened to green marketing?," Crane and Peattie (1999) ask, and they state that in spite of tremendous activity and research, green marketing seems to be mostly unsuccessful.

Acquiring environmental information is not necessarily reflected in environmental attitudes and even less so in pro-environmental consumer behaviour (Nemcsicsné Zsóka 2005). Uninterested consumers represent the vast majority of society, and the products they usually buy exert significant impact on the environment. Those consumers should be addressed in more indirect ways, without trying to build on their non-existing environmental awareness. Current consumer policy measures are respectable but are still unable to achieve the breakthrough needed in the area. Most consumer policy-related academic articles still focus on "green consumerism," meaning "green" consumers buying products positioned as "green." The challenge is to urge uninterested consumers to buy products with reduced environmental impacts or to use solutions/services which help reduce environmental impacts (e.g., better insulation). The total environmental benefit reached by appropriate consumer policy tools for uninterested consumers plus "green" consumers can be considerably greater than by using merely "green" positioning - as will be presented in the case study later in this article.

As mentioned above, housing and related energy use has a significant share in consumption-generated environmental impacts. Heating and cooking equipment, hot water generation equipment, electric energy-using products, and housing construction contribute most heavily to this environmental impact (van Raaij and Verhallen 1983; Tukker and Jansen 2006). Hence, housing-related energy use seems to be a field of action, where considerable social and environmental benefits can be realized. Our aim is to show the efficiency of consumer policy can be increased by combining cost effectiveness analysis with the profiling of mitigation options in a way that results in reaching mitigation targets with the least possible social cost and effort.

\section{A Model for Assessing and Maximizing the Impacts of GHG-Related Consumer Policies}

In this section, a model for the comparison of consumer policy tools regarding GHG emission mitigation will be presented in three phases. To start with, the marginal social cost curve is constructed and analysed. In the second phase, the mitigation options with negative marginal social cost are selected, as they are the most promising to be promoted and implemented. In the third phase, the selected mitigation options are assessed by the profiling technique, which contains several relevant evaluation criteria and helps in building up an effective implementation strategy.

The paper follows a cost-efficiency approach rather than a cost-benefit approach when calculating the cost curves. Thus, instead of comparing benefits with costs, we set our focus on using resources in order to reach the maximum possible energy savings. Theoretically, costbenefit analysis is considered superior to cost-efficiency analysis (see Mishan and Quah 2007). 
However, in our case, the most positive externalities are the same for all projects. Climate change impacts, taken proportional to energy saving potential, are reflected by the horizontal axis of the curve. Estimation of other benefits, e.g., external social benefits of energy savings, inter-sectoral impacts, or benefits for future generations, is a controversial issue and results in estimations with very wide range. Cost-benefit analysis might be a proper tool when deciding on one specific large-scale project, but it cannot give reliable numbers when comparing 20 different policy measures, as required by our analysis. Thus, in order to preclude benefit estimation problems, we decided to follow the cost-efficiency approach.

The European (including Hungary) energy policy suggests the same approach when setting the so-called 20-20-20\% energy targets to be met by 2020 . These are a reduction in EU GHG emissions of at least 20\% below 1990 levels, 20\% of EU energy consumption to come from renewable resources, and $20 \%$ reduction in primary energy use compared with projected levels, to be achieved by improving energy efficiency (http://ec.europa.eu/ environment/climat/climate_action.htm). Those targets are very ambitious for certain countries that have to rethink current policies in order to be able to reach them.

\section{Construction of the Marginal Social Cost Curve}

Allocation of social resources in a way that maximizes social welfare is the primary ambition of economists. Actions taken in order to mitigate climate change impacts will divert resources from alternative social uses. Such use of limited assets can be justified only if

- Mitigation actions contribute to the increase in social welfare. The social benefits of mitigation offset all social opportunity costs of those actions.

- Resources are used in the most efficient way, meaning that climate policy targets are reached by the least possible costs.

Almost no doubts have been raised about the first statement. The Stern (2008) report found that benefits outweigh costs. At the same time, little attention is paid to the second aspect. Decision makers are under pressure from different stakeholder groups concerned about potentials and threats of climate policy. Decision makers also have their own views and values (e.g., putting less burden on the poor and helping spin-off innovations in "green" energy) and have different attitudes towards risk. Thus, the cost of actions is often only one of several factors in the decision-making process. Still, cost assessment should become a more integrated part of policy planning in order to minimize the effort and sacrifice needed to reach climate targets and also to seize lost opportunities when deciding which path to take.

The marginal social cost curve for mitigation options presents the costs of mitigation options in an explicit way. In this paper, the marginal social cost curve will only cover financial costs, although there are several indirect costs related to GHG mitigation options as well (see Zilahy et al. 2000). The reason for limiting the social costs to financial costs is that the scale of indirect costs is so wide that the uncertainty in ranking of options would have significantly increased if they had been included. The following section shows how the marginal social cost curve can be constructed and used in consumer policy decision making. Construction of the marginal social cost curve of mitigation consists of the following steps:

1. Building the baseline scenario. The baseline will present the "without policy" option. GHG emission will increase when no policy is adopted due to the increasing income and energy demand of society.

2. Identification of mitigation options (e.g., improving insulation, replacing windows, switching to CFL or LED bulbs, and photovoltaic cells). 
3. Assessment of mitigation potential for each option as well as assessment of marginal social costs of that option, construction of the marginal social cost curve for selected mitigation options, and construction of mitigation scenarios that integrate multiple mitigation options.

4. Profiling and assessment of policy implementation.

Building the baseline scenario and identification of mitigation options primarily require technical qualifications. Economists enter the picture when these tasks are completed. They are concerned about picking the cost-efficient options. Bottom-up approaches calculate abatement potentials and costs from project to project. We need information about the levelled costs of abatement and the potential GHG savings for, preferably, all significant options. The bottom-up marginal abatement cost curve for GHG emissions abatement can be constructed by plotting GHG abatement prices against a corresponding reduction amount for specific abatement options. Then, all the options are arrayed from lowest to highest costs in order to construct the marginal abatement cost curve of GHG reduction options (for an example, see Fig. 2). Marginal abatement cost curves show the relationships between the tons of GHG emissions abated and the unit price of abatement.

The total social cost of abatement is the area under the positive side of the marginal abatement cost curve minus the area under the negative side of the curve.

Selecting GHG Mitigation Options with Negative Marginal Social Costs

The McKinsey report (Creyts et al. 2007) found that, in the USA, almost $40 \%$ of abatement could be achieved at negative social cost, which means that investing in these options

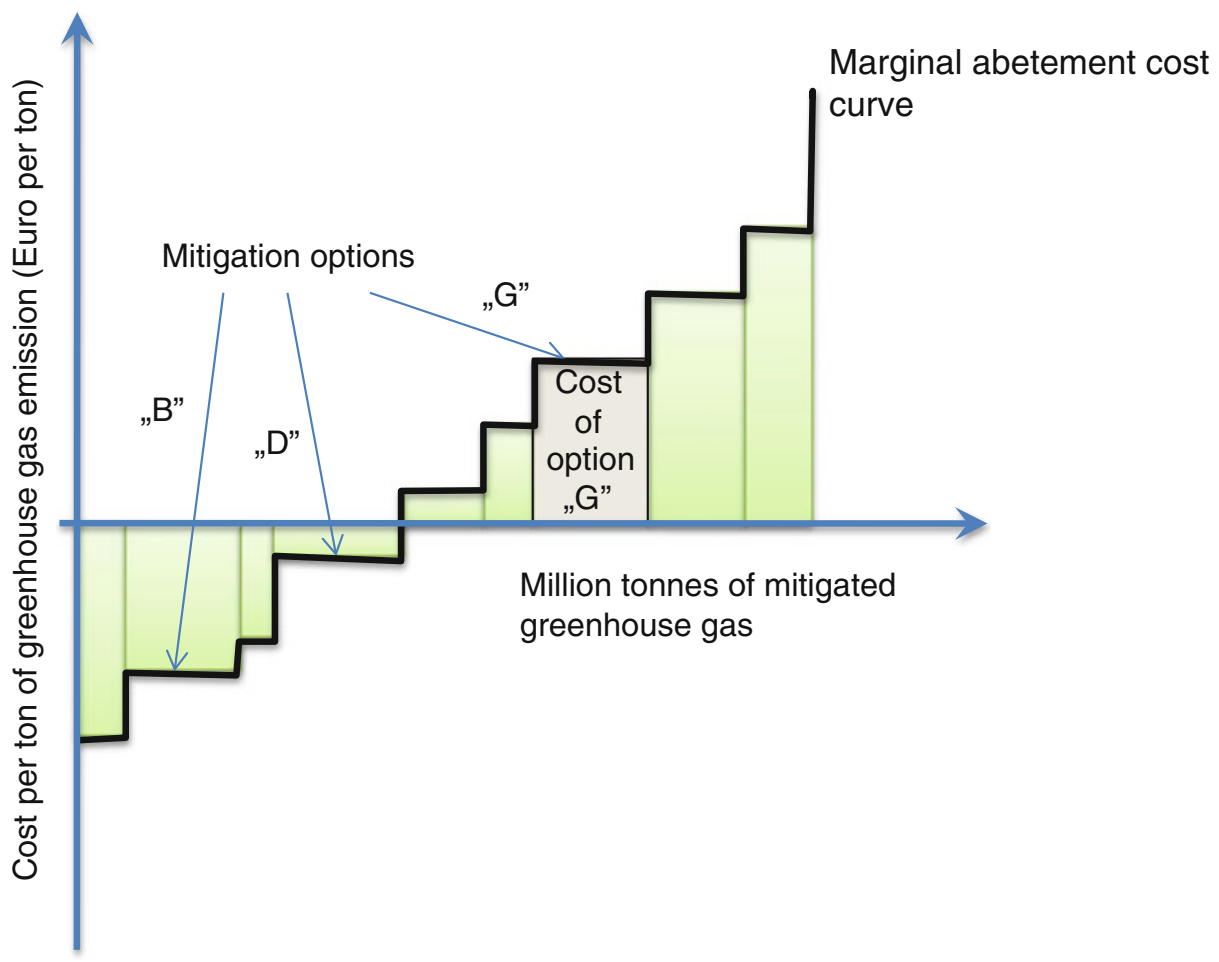

Fig. 2 Construction of the marginal social cost curve of abatement (source: Based on IPCC 1997) 
would generate positive economic returns over a lifecycle. These options are often labelled as "no-regret." The report estimates the biggest abatement potential for improving energy efficiency in buildings and appliances. Wesselink and Deng (2009) analysed cost scenarios for the EU27 and found that half of the options fell into the negative social cost zone.

If there are so many "no regret" options, why are these opportunities often not realized? The answer partly lies in the difference between marginal private costs and marginal social costs of abatement. The curves for social costs and for private costs both stem from summing up the marginal abatement cost curves horizontally. The difference is how costs were calculated (e.g., taking into account taxes, transfers, and private and social discount rates). The sign sigma in Figure 3 is used to indicate that private and social costs of selected product groups are calculated at the national level rather than for a single producer.

Negative marginal social costs do not necessarily mean that private costs are negative. National marginal abatement cost calculations are carried out on the basis of social costs, by correcting market prices for market inefficiency, externalities, market distorting regulations, subsidies, and taxes. Logic dictates that public policy should concentrate on projects with high abatement potentials and low, preferably negative, social costs. Figure 3 illustrates that for certain abatement options, marginal social costs might be negative, while marginal private costs are still positive. They are worth implementing for the society, but not for the individuals. Using a traffic light analogy,

- Green zone options pay back both for the society and for the individual. They are likely to penetrate the market without intervention, although this penetration may take time depending on the technology involved.

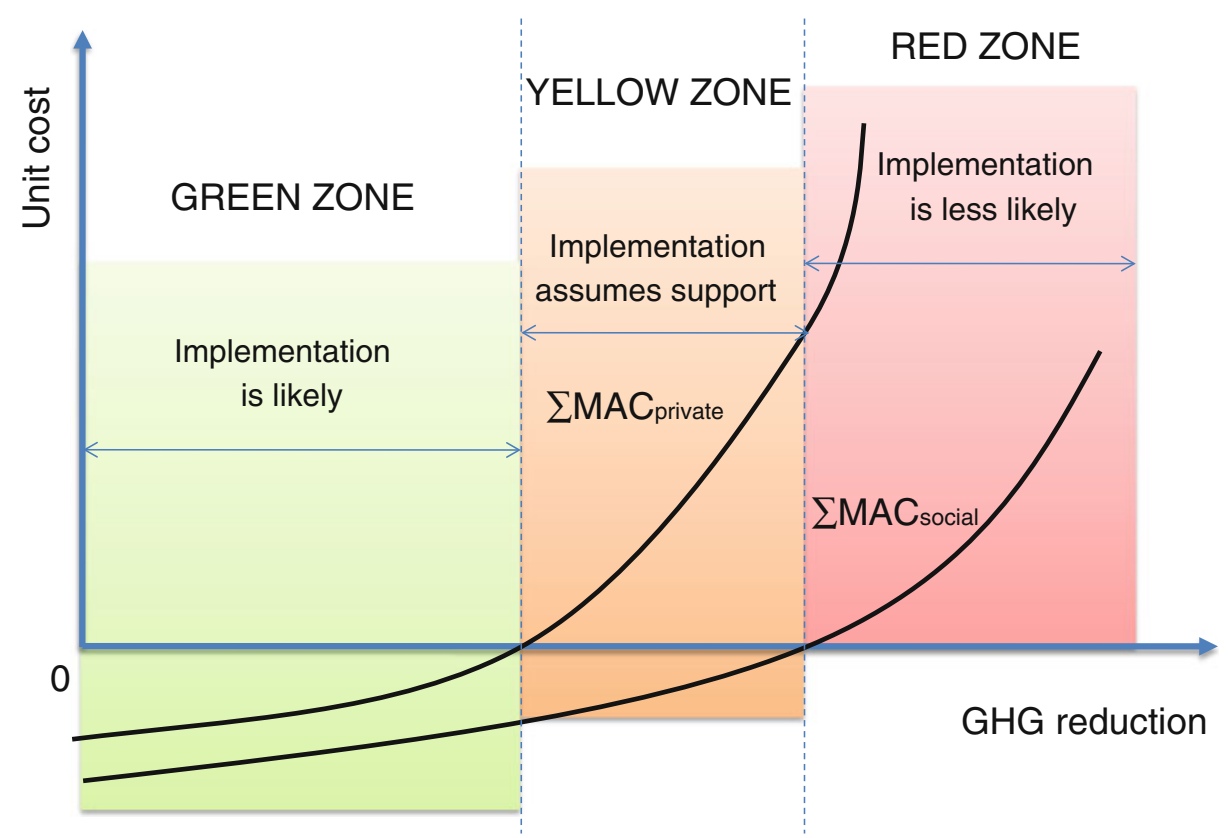

Fig. 3 Implementation chances of GHG reduction options, based on marginal social and marginal private costs 
- Yellow zone options pay back for the society, but not for the individual. This is the major arena for policy. The options definitely need public policy intervention and investment, but those efforts will pay back for the society.

- Red zone options neither pay back for the society nor for the individual. They can only be promoted under very special circumstances (e.g., in spin-off technologies).

Above cited studies suggest that there is a huge potential in household energy saving and that the options with the most environmental potential fall into the green zone (see Creyts et al. 2007; Wesselink and Deng 2009). However, there is still an implementation gap between the huge potential and actual achievement, which makes a further assessment of the selected green and yellow zone options necessary, from the point of view of consumer policy design. Profiling helps to identify barriers and cope with them, especially in the case of yellow zone options.

\section{Identifying Implementation Barriers-Use of the Profiling Concept}

- In spite of their negative marginal social costs, green and yellow zone options involve a series of widely known and frequently mentioned barriers for the consumer policy designer. Up-front investments are seen as major barriers for the private sector (see Baden et al. 2006). Up-front costs may be prohibitive for lower income families who often lack proper access to capital (see Jakob 2007), even if an investment (e.g., additional insulation) would pay back over reasonable time.

- Lack of information on options, potentials, and cost effectiveness or lack of awareness (see Jakob 2007) even when the information is available (e.g., LED bulbs).

- Long lifetime of certain technologies may impede implementation. Less efficient boilers or draughty windows are held on to until they get into bad physical condition.

- Habits, fashion, insisting on the well known (e.g., unusual form of CFL or LED bulbs).

- Perceived risks involved in new solutions (e.g., alternative energy use at home).

- Lack of a sufficient marketing budget to enable producers to disseminate information about new solutions (e.g., window film reflecting sunrays).

- Massive marketing by certain companies, which works against these options (e.g., massive marketing of air conditioning equipment works against energy saving shading solutions). Certain solutions, e.g., insulation or shading, are sold by small or medium size companies that cannot compete with the marketing power of air conditioning equipment producers.

- Low energy prices do not encourage energy efficiency measures (Jakob 2007).

- Split incentives or insufficient incentives to make pertinent decisions, meaning "inadequate or inefficient policies often create more barriers rather than ease them" (Hinostroza et al. 2007, p. 31).

- Indirect costs and benefits of the options (see Zilahy et al. 2000) are not recognized.

- Financial and technological risks also cause difficulties (Jakob 2007).

Beyond social costs, the above listed barriers as well as the benefit potential must be considered in the assessment. In the following, the concept of profiling, borrowed from risk management, will be presented as a useful tool for evaluating public perception of GHG mitigation options. Hazard profiles have been used for a long time in environmental decision making for prospecting public perception of new, unknown, or high scale risks (see Slovic 1987; Slovic and Weber 2002). In consumer policy, profiling seems to be especially useful for anticipating public perception of proposed consumer policy actions and designing implementation strategy for a new, innovative solution. When an innovative and a conventional option share the same profile, similar public reaction can be expected, 
and thus a strategy, which was successful for the conventional option, can be used to tackle barriers hindering the innovative solution.

Table 1 summarizes the most important factors for the assessment of the selected GHG mitigation options. Every option can be characterized by specific scores given to the option for each evaluation factor.

Table 1 gives a general overview of designing scores to factors of profiling. Scores must be policy-specific and country-specific. Later, in the "Case Study: Evaluation of the Hungarian GHG-Related Consumer Policy" section, a more detailed example will be given with data on energy efficiency options for the Hungarian residential sector.

Implementation barriers are allocated into four categories: cost, benefit, cooperation, and risk factors. Categories were chosen in a way that points toward a solution and hints at implementation strategy.

Table 1 Evaluation factors and their scores for the profiling of GHG mitigation options

\begin{tabular}{|c|c|c|c|}
\hline & Prohibitive for mass market & $\begin{array}{l}\text { Contingent, requires } \\
\text { external support }\end{array}$ & Acceptable \\
\hline & Score, $1-3$ & Score, 4-6 & Score, 7-9 \\
\hline \multicolumn{4}{|l|}{ Cost factor } \\
\hline $\begin{array}{l}\text { Initial investment } \\
\text { cost (private) }\end{array}$ & High & Medium & Low \\
\hline $\begin{array}{l}\text { Private cost-based } \\
\text { payback period }\end{array}$ & More than 10 years & $6-10$ years & Less than 6 years \\
\hline $\begin{array}{l}\text { Marginal social } \\
\text { cost of } \\
\text { implementation }\end{array}$ & High & Slightly positive & Negative \\
\hline \multicolumn{4}{|l|}{ Benefit factor } \\
\hline $\begin{array}{l}\text { Environmental } \\
\text { benefits }\end{array}$ & Low & Medium & High \\
\hline Co-benefits & Low, non-quantifiable & Some benefits & $\begin{array}{l}\text { Medium to high, at least } \\
\text { same range as energy } \\
\text { savings }\end{array}$ \\
\hline $\begin{array}{l}\text { Compromise } \\
\text { required from } \\
\text { customers }\end{array}$ & $\begin{array}{l}\text { Perceived as high } \\
\text { (acceptable only to less } \\
\text { than } 10 \% \text { of people) }\end{array}$ & $\begin{array}{l}\text { Perceived as medium } \\
\text { (acceptable to } 10-30 \% \\
\text { of people) }\end{array}$ & $\begin{array}{l}\text { Perceived as low } \\
\text { (acceptable to more } \\
\text { than } 30 \% \text { of people) }\end{array}$ \\
\hline \multicolumn{4}{|l|}{ Cooperation factor } \\
\hline $\begin{array}{l}\text { Chance to build } \\
\text { strategic } \\
\text { alliances }\end{array}$ & No or low interest (1-3) & $\begin{array}{l}\text { Some interests from } \\
\text { certain partners }(4-6)\end{array}$ & $\begin{array}{l}\text { High interest in several } \\
\text { partners }(7-10)\end{array}$ \\
\hline $\begin{array}{l}\text { Integration with } \\
\text { other policies }\end{array}$ & Other policies work against & Neutral & Good integration \\
\hline $\begin{array}{l}\text { Counter-interested } \\
\text { market agents }\end{array}$ & $\begin{array}{l}\text { May threaten the success } \\
\text { of the policy }\end{array}$ & Can be neutralized & Low lobbying power \\
\hline $\begin{array}{l}\text { Information and } \\
\text { marketing } \\
\text { requirements }\end{array}$ & $\begin{array}{l}\text { Difficult to get } \\
\text { stakeholders involved }\end{array}$ & $\begin{array}{l}\text { Stakeholders can be } \\
\text { informed at low costs }\end{array}$ & Well informed stakeholders \\
\hline \multicolumn{4}{|l|}{ Risk factor } \\
\hline $\begin{array}{l}\text { New or common } \\
\text { technology }\end{array}$ & New & Medium & Common \\
\hline Trust in policy & Low & Medium & High \\
\hline
\end{tabular}


The cost factor includes up-front investment costs, net private cost of implementation (or payback), and net social costs of implementation. Insulation has negative social but positive net private cost. The payback period is viewed as too long for many owners living in houses built more than 20 years ago.

The scales of the private cost-based payback period are based on our latest representative survey of 1000 respondents, regarding consumption patterns and their impact on environmental indicators in 2010 (not published yet). The survey indicated that $38 \%$ of house owners would strongly consider installing supplementary insulation in the future, while $29 \%$ are sure they will not do so. For alternative energy, these numbers are $22 \%$ and $51 \%$. These findings suggest a strong public recognition of insulation options and the presence of a mass market. Still, the retrofit rate is very low and driven by government subsidy programmes.

Experience suggests that investments with more than 6 years payback period are less acceptable for the Hungarian mass market, even for long-term projects. Different calculators and studies (e.g., http://www.napkollektor-info.hu/component/poll/16) suggest 5-8 years maximum accepted payback period for retrofit projects, e.g., insulation. Still, according to the Hungarian Statistical Office, only about 1\% of apartments and buildings with poor or no insulation is annually retrofitted, including projects carrying out only inexpensive internal insulation (KSH 2005). Projects with a 7-9-year payback period are less likely to penetrate the mass market. Central and local government subsidies drive the insulation retrofit market ( $60 \%$ subsidies can be gained for investments: $30 \%$ from the state, $30 \%$ from the local government). Without those subsidies, the niche for this market is narrow, although people are aware of the advantages and importance of insulation projects.

The public is less likely to take on renewable energy projects (see http://www. napkollektor-info.hu/component/poll/16). The $22 \%$ acceptance rate and $51 \%$ rejection rate indicate doubts. A positive response bias can also be supposed, so real numbers might be even less supportive.

Among benefits, environmental benefits refer to the environmental potential, while cobenefits include increased value of homes, comfort level, prestige, longer lifetime of CFL bulbs, etc. The range is policy and country specific. For Hungary, 100 and $1000 \mathrm{GWh} /$ year seem to be meaningful as the lower and upper limits of energy saving options in the contingent zone, where state support is needed. For larger countries, those values will be larger.

Compromise required from the customers refers to non-monetary sacrifices, monetary costs being included in the cost factors. Compromise can involve availability of the product or solution, lacking institutional and infrastructural background, compromise in product features compared to substitutes, or sacrifices needed when choosing the product or solution. Compromise detracts from benefits. The compromise is considered "prohibitive for mass market" if an option will raise interest only among green consumers, covering less than $10 \%$ of the market. The minimum limit for mass-market penetration is set to $30 \%$. This might seem low, but European surveys show that market penetration is slow even in the case of "green zone" options (Bertoldi and Bogdan 2006a, b).

The cooperation factor indicates potentials and barriers to cooperate in order to penetrate the market with a solution. A low chance to build strategic alliances is a barrier when, for example, alternatives to air conditioners (e.g., shades) are promoted. Shades are installed by small enterprises, which are not as well organized as the few players of the more concentrated air conditioning market.

Not only actors of the market but also policy actors could build strategic alliances. The housing block programme in Hungary proved to be an area where green consumer policy 
was able to cooperate with economic policy (see later in the "Case Study: Evaluation of the Hungarian GHG-Related Consumer Policy" section).

Integration with other policies is very important. For example, Eurocodes, the European building codes, require certificates for newly built homes, thus encouraging energy-efficient construction design (CEN Technical Committee 250 2010). At the same time, building codes promote bigger homes with bigger rooms by regulating the minimum size of a room, which results in higher energy consumption. While energy efficiency is promoted in office buildings, the maximum temperature is set at $24^{\circ} \mathrm{C}$ for workplaces by regulation. This is an implicit way of making air conditioning mandatory in many countries.

Counter-interested market agents can make it difficult to push through beneficial solutions. Low energy prices reduce the profitability of energy saving solutions. The fossil fuel industry keeps lobbying for maintaining the wide array of subsidies common to the industry.

Based on the scores for each factor, the consumer policy profile of the selected GHG mitigation options can be drawn. Figure 4 shows three examples, which are significantly different in their profiles, without numbers to illustrate the logic of profiling. Numbers are

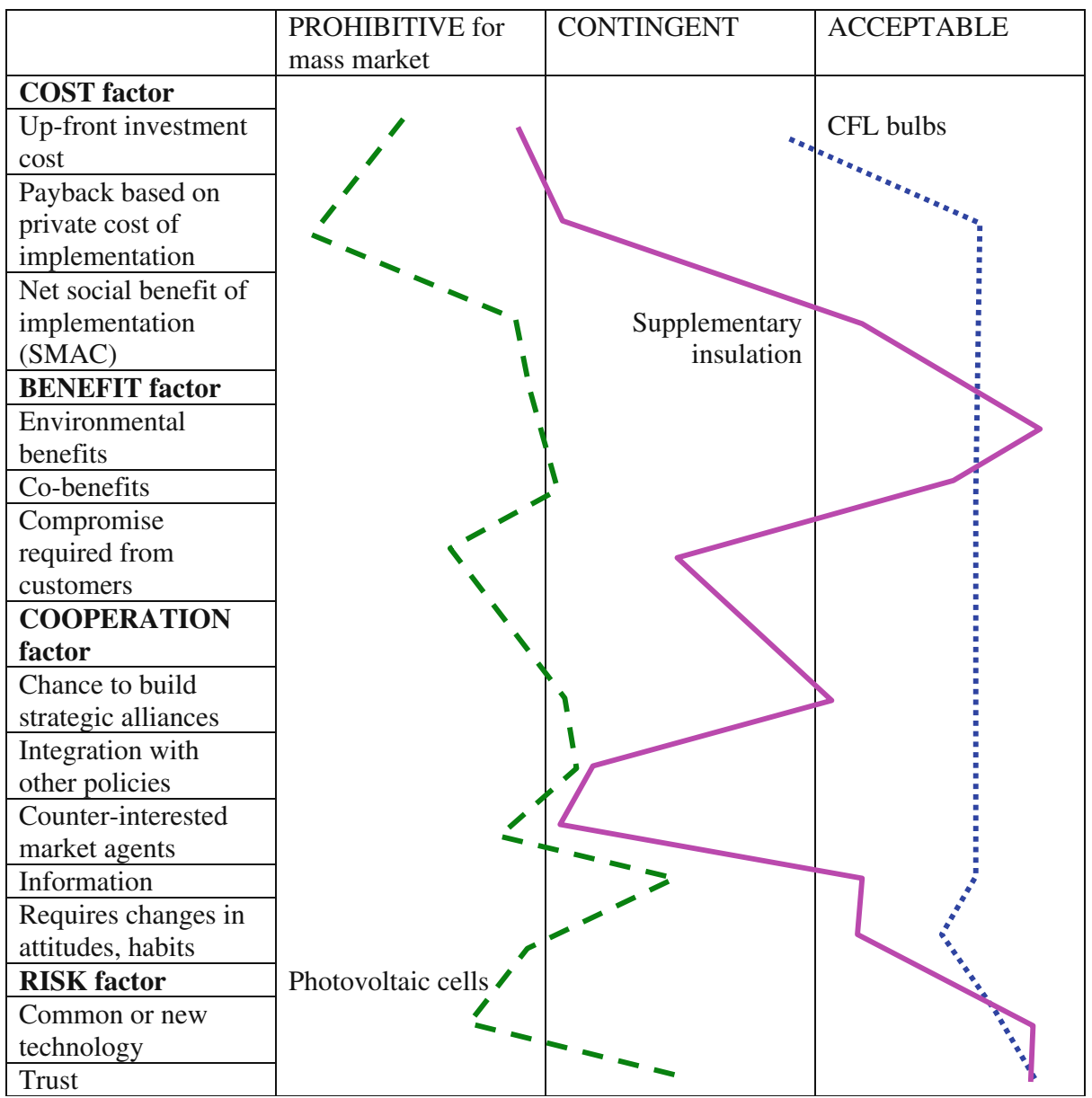

Fig. 4 Using profiles for designing an implementation strategy 
given in Figure 7 in the "Case Study: Evaluation of the Hungarian GHG-Related Consumer Policy" section.

At least in Hungary, the photovoltaic cell is a typical "red zone" option, tradable only to wealthy green consumers. There is little chance for these cells to penetrate the mass market. It would take more than 10 years for the installation to pay back even with a $50 \%$ investment subsidy. Insulation is a typical mass-market option from the "yellow zone" with huge environmental potential and negative social costs. High up-front costs and low access to capital is still a problem for many families considering this option. CFL bulbs fall into the "green zone," but they are still expensive for the poorest.

Designing policy implementation involves pushing the curve into the acceptable zone. Costs of consumer policy can be significantly reduced if there are economic agents who find co-benefits in the proposed solution and are willing to invest in promoting it.

\section{Pushing and Pulling the "Profile String"}

The profile should be seen as a flexible string rather than a curved rigid pole. Pushing a certain point of the string impacts and changes other points as well. Thus, working on a feature falling into the prohibitive zone is not the only approach the policy may take when addressing the barriers of implementation. The policy may rely on and take advantages of features where the option was given high scores.

For example, the profile of the "insulation" option reveals prohibitive investment costs but good co-benefits and a high chance to build strategic alliances. Co-benefits include energy saving and increased value of the property. Potential strategic partners can be found among local entrepreneurs and among financial institutions. Consumer policy, then, may focus on

- Reducing investment costs by subsidizing investment and building strategic alliances with the building industry. Subsidies increase demand for the building industry, so the industry might want to take over the marketing tasks; or

- Quantifying co-benefits like increased value or marketability of the rebuilt home. Investment costs seem to be relatively lower when they serve several purposes; or

- Building strategic alliances with banks. The financial institution provides loans for the insulation investment, and the payback comes from energy savings; or

- Lobbying against subsidizing the (non-renewable) energy prices or the fossil fuel industry.

Thus, the prohibitive nature of high insulation costs might be solved by better cooperation with other actors.

\section{Case Study: Evaluation of the Hungarian GHG-Related Consumer Policy}

"The way energy is consumed in Hungary differs from the EU average, with household and commercial activities covering the largest share. Households alone account for more than a third of energy consumption (the EU-25 average being 26\%)" (European Commission 2009). Heating and cooling of buildings are responsible for $30 \%$ of all energy consumption in the country, while energy efficiency is far below the European average.

In the following, the Hungarian GHG-related consumer policy will be assessed, using the model introduced above as framework. Based on marginal social cost curves from 1998 to 2008 , a comparison will be made of the Hungarian energy efficiency policy at the two points in time. 
Positioning the Same Policy in Three Different Ways

As a result of the project: "Economics of Greenhouse Gas Limitation," initiated in 1998 by UNEP Global Environment Facility and the RISO laboratory, the first marginal social cost curve for GHG mitigation options was prepared for Hungary. The project was supervised by the Ministry for Environment and Regional Policy and became part of the national Communication on the Implementation of Commitments under the United Nations Framework Convention on Climate Change. Figure 5 illustrates the marginal social cost curve for energy saving options.

The marginal social cost curve suggested the biggest energy saving potential at low cost for supplementary insulation, replacement of windows, and more efficient boilers. The Hungarian government launched its energy savings action programme in 1999, aimed at making buildings more energy efficient and supporting the use of renewable energy (Government Decree of 1107/1999 (X.8)). The programme had three target groups:

- Inhabitants of buildings built with industrial technology (housing blocks). These blocks of houses were built as cheap housing for low- and middle-income families before 1992, but mainly during the 1960s and 1970s. Austere construction design made them "energy-eating monsters" approaching the end of their lifespan. People living in them lacked money to invest and were worried about the fast deterioration and subsequent loss in value of their homes. Co-benefits of energy-efficient reconstruction included increasing the lifespan, value, and energy savings of blocks included in the programme.

- Inhabitants of houses built with conventional technologies serving middle- and highincome families. Families living in these might or might not have had some savings but were still worried about the high investment costs of supplementary insulation or replacement of windows. Their houses were more marketable than apartments, but they

Marginal cost curve of mitigation options, calculated in 1998, $r=3 \%$

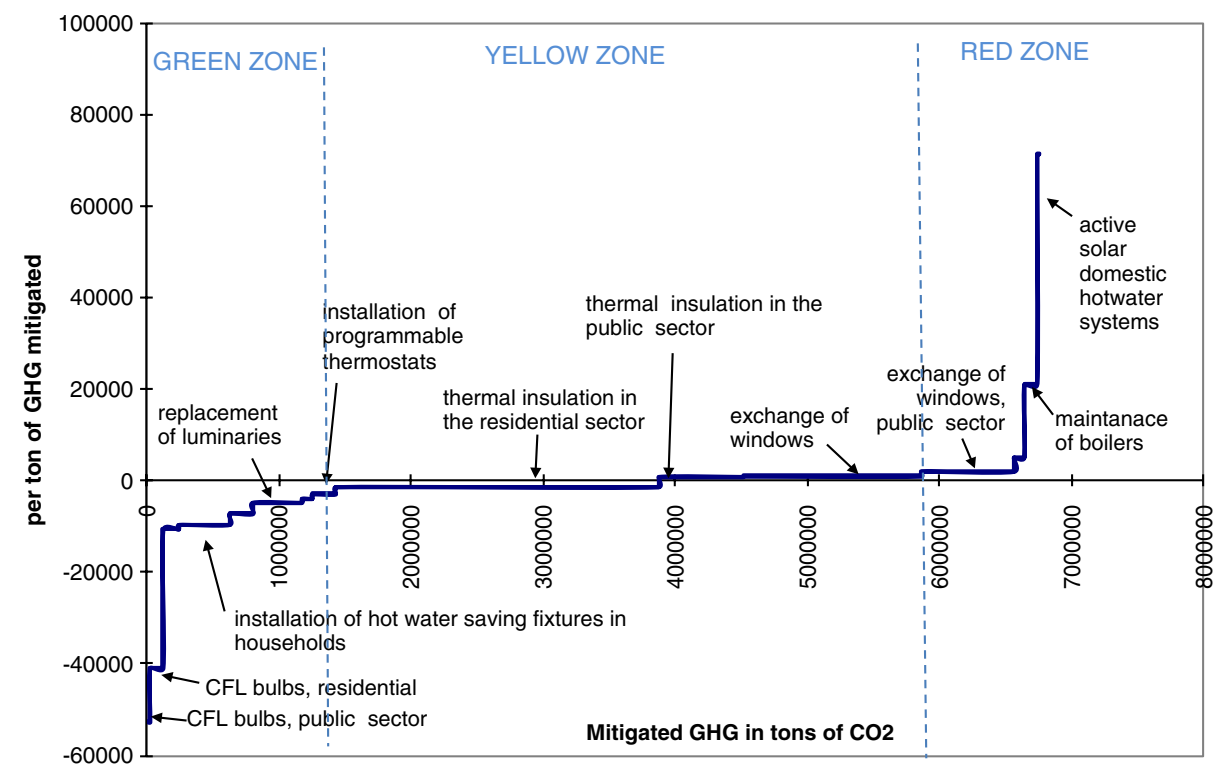

Fig. 5 Marginal social costs of energy savings options (based on Csutora and Zilahy 1998) 
were wasting too much energy. Co-benefits included energy saving, resulting in reduced energy bills. Major implementation barriers were high initial costs of investments and the "why change it if it is still working" approach, as windows, insulation, or boilers are long-term investments with very long lifespan.

- Operators of public buildings and offices and production buildings of small and medium size companies. Co-benefits here included energy savings and the public image of being an "environmentally aware" entity and even more importantly: being a "smart local government" gaining public money through proposals. Although the policy for private consumers is usually different from the policy for public and business consumers, the Hungarian government did not really make a distinction when promoting its energy saving policy at that time. Furthermore, small businesses often tend to behave similarly to the public in Hungary, especially when as in this case government policy was solely targeted at energy improvement measures in buildings.

In most cases, the programme embraced replacement or upgrading of windows and doors in order to reduce heat loss, supplementary insulation, replacement or upgrading of out-dated boilers, increasing the use of renewable energy for the heating, cooling, or production of hot water, as well as energy efficiency in heating, air conditioning, and hot water systems.

State-supported credits and subsidies were offered up to $30 \%$ of the total investment. In the case of the panel programme, local governments also contributed with another $30 \%$ of investment costs.

The programme was positioned and communicated in different ways towards the three target groups:

- The "panel programme" belonged to the Ministry of Local Government and was communicated as a home reconstruction programme, emphasizing increased durability and increased market value of homes. Sometimes, it resulted in misunderstandings and disappointment, as supported families thought reconstruction included other, not energy-related activities, but the programme was actually limited to energy efficiency measures. Still, it hit the target and became very popular.

- The programme for conventional buildings was set up as an energy efficiency programme, run by the Ministry of Economy at first, but later taken over by the Ministry of Transport, Telecommunication, and Energy. It so happened that the annual budget ran out in 2 weeks due to the high number of project proposals. In 2009, state aid was available only to support the use of alternative energy for heating, cooling, etc.

- Only the last one, energy saving in public and small commercial buildings was communicated as an environmental programme, budgeted and run by the Ministry of Environment. Here, we found the shortest queue for free money. Newspaper ads were even run in November 2009, suggesting that aid from the annual budget was still available and proposals were welcome.

The marketing costs of the programme were shared among different stakeholders (see the factor "chance to build strategic alliances"). Construction industry participated intensively in the process, mobilizing its marketing efforts, which significantly increased the effectiveness and efficiency of the programme.

The whole programme was promoted as an "energy saving programme" included in the wider environmental programme. Target groups of all three sub-programmes became consumers of energy efficiency equipment including insulation, condensing boilers, solar cells, active solar hot water systems, etc. Each of the above-mentioned items might have 
different selling points, and the government programme emphasized different aspects. Still, all three sub-programmes focused on saving energy and fighting climate change. We are not saying that segmentation was the result of a conscious and deliberate consumer policy design in each case, but still, the differentiated policy made a lucky hit that produced significant environmental benefits and reached different consumer segments, both uninterested and environmentally conscious consumers, a broad segment of the society.

\section{Current GHG-Related Consumer Policy}

Based on the data of Novikova and Ürge-Vorsatz (2007) about carbon dioxide mitigation potential in the Hungarian residential sector, we constructed the updated marginal social cost curve of GHG mitigation (see Fig. 6).

In Figure 6, mitigation options are highlighted where financial support can be applied in order to implement the project. The figure does not contain photovoltaic cells and wind power plants, which, being at the top of the curve, indicates that they are real "red zone" options.

Figure 6 suggests that the support programme of the state should focus on the insulation of earlier built houses and energy saving construction of newly built houses (e.g., passive house technology). These measures would result in huge energy savings in ways that would pay back to the society.

The National Energy Saving Programme (NEP 2009) can be evaluated on the basis of the model, using the marginal social cost curve as basis, and the profiling concept to identify and battle barriers to implementation.

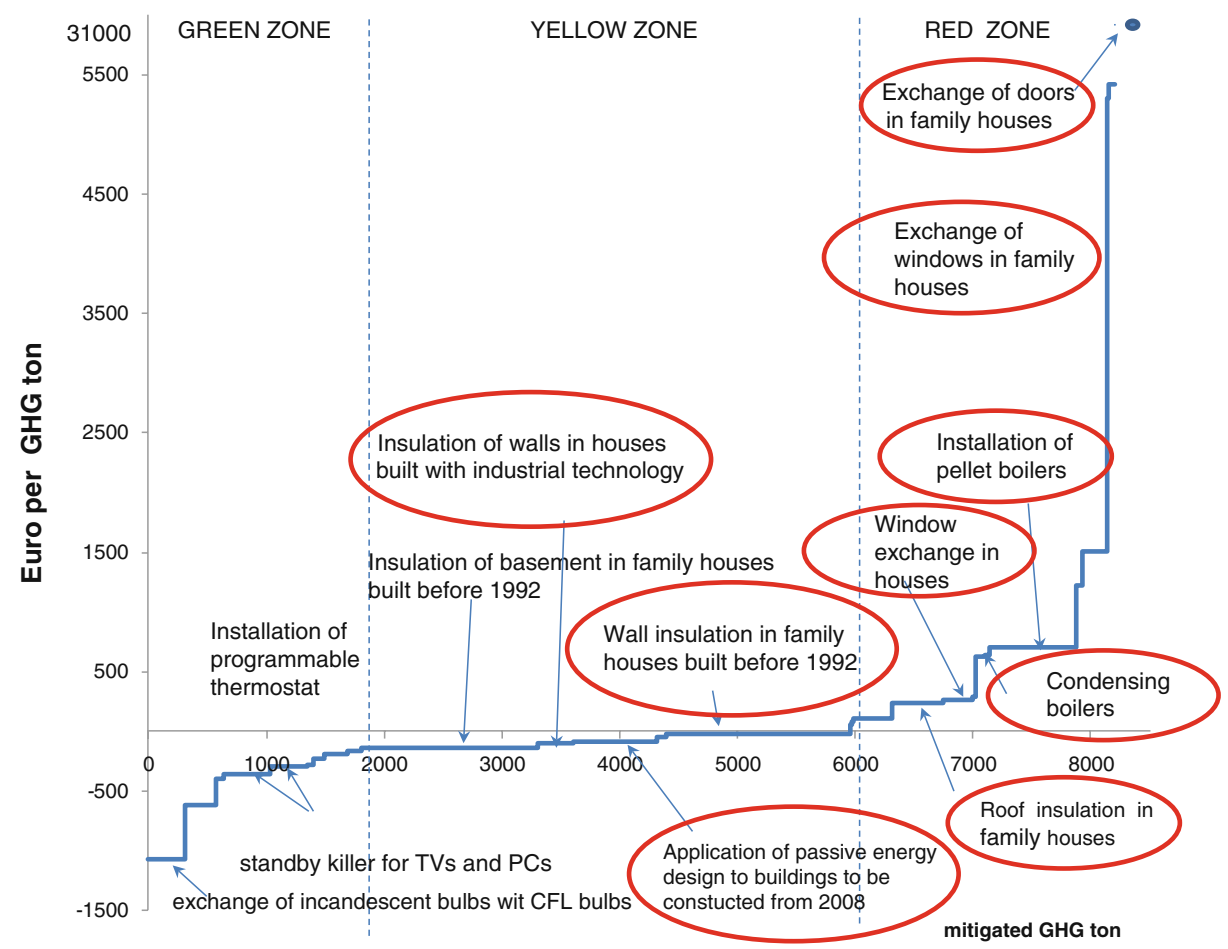

Fig. 6 The marginal social cost curve of GHG mitigation for the Hungarian residential sector (data source: Novikova and Ürge-Vorsatz 2007) 
- Supporting the construction of energy-efficient houses, shading techniques, and insulation of walls are positive elements of the programme.

- Renewable energy investments and implementation of photovoltaic cells do not pay back in reasonable time, even if $30 \%$ state contribution is offered. It means that those options can be positioned for a wealthy, environmentally aware market segment and may attribute high prestige to environmental protection investments. Mass-market penetration of those options cannot be expected. Replacement of doors is an option that entails extremely high costs but small GHG mitigation potential. Hence, financial support for this option can be seen as social support (e.g., reconstruction of deteriorated, old houses).

As example, the assessment profile is drawn for two options-insulation of walls (a yellow zone option) and photovoltaic cells (a red zone option) - in order to evaluate barriers and design an appropriate implementation strategy (see Fig. 7). For measuring costs, benefits, payback, and environmental benefits in terms of GHG savings potential, the same data were used as for constructing the marginal cost curves (Figs. 5 and 6).

As some factors of the profiling are difficult to calculate, there is a need to use ordinal scales for evaluation in some aspects. "High" and "low" may have very different meaning from one aspect to another (see Table 1).

Judgments regarding co-benefits such as increased living comfort, protection against external noise, and improved leasing potential are based on Jakob (2006) and Zilahy et al. (2000); compromises required from the consumers are measured in our latest survey of a 1000 respondent (representative) sample in 2010 (not yet published).

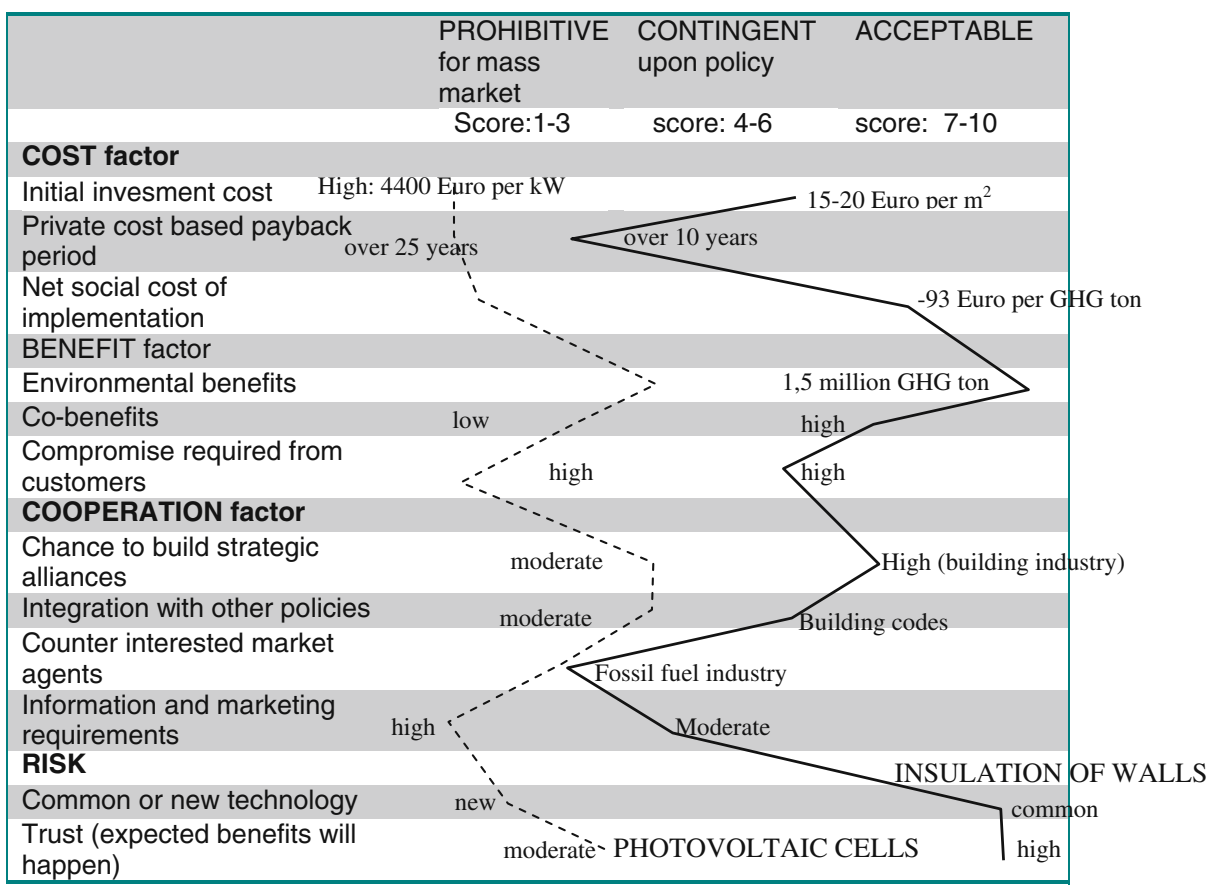

Fig. 7 Profiling of two selected GHG mitigation options (costs and benefits are calculated using own data as well as data from Novikova and Ürge-Vorsatz 2007) 
The co-operation factor was measured by the intensity of cross-references to other stakeholders (cross-references in homepage to other stakeholders, e.g., energy auditors, grant schemes, and proposal editing services). Enterprises specializing in selling insulation technologies or renewable technologies offer their customers the grant programmes of the state. In 2001, 7.67\% of the energy efficiency grant budget was spent on informing potential consumers about grant possibilities. By 2004, this was reduced to 0\% (http:// palyazatok.org). In this case, three different stakeholder groups co-operate: municipalities, the building sector, and households. The state has only to place grant application forms on the Internet for interested parties get the information. Building sector enterprises approach representatives of blocks of houses, offering help in building reconstruction as well as in writing grant proposals. Word-of-mouth communication is also active. There is no need for active marketing of the "climate friendly home" programme, as interested enterprises seem to take over this burden. "The National Cooperation Program," published in May 2010, deals with the support mechanism offered to small- and medium-sized companies in the construction industry and explicitly mentions supporting energy-efficient building programmes, green technologies, and energy-efficient systems.

We based our calculation of rebound effects on Dowling and Staelin (1994), Nässén and Holmberg (2009), and Reinhard and Biermayr (2000).

Perceived risk can be, e.g., wasting money, adverse effects on lifestyle, as well as wasting time. We associated the level of technology-related market risk with the strategies consumers may use to reduce their perceived risk. Roselius (1971) identifies 11 risk reduction strategies: endorsements, brand loyalty, brand image, private testing, store image, free samples, moneyback guarantees, government testing, shopping, expensive models, and word-of-mouth communications. Other studies also indicate such strategies as extensive search for more information (Akaah and Korgaonkar 1988). The perceived risk literature is especially plentiful in the field of online shopping and e-services-related risks (e.g., Featherman and Pavlou 2003).

Solar cell technology was labelled as risky because it requires high financial engagement, but most of the conventional risk-controlling strategies cannot be applied either chiefly because of the nature of the technology or for market reasons (European Commission Joint Research Centre 2009).

Insulation services are offered mainly by local small enterprises specializing in other construction-related activities as well. Consumers can easily find an insulation service provider with whom they or someone they know have had business contacts before (wordof-mouth communication). In addition to personal experience and the experience of other people, consumers can rely on store image or brand image to reduce their risk. Information about trust and information factors are taken from Eurobarometer 295 and from our own survey mentioned earlier.

The market penetration of solar cells is low in Hungary at the moment. During the period 2001-2004, there were only nine applications for solar cells, while there were 562 for active solar domestic hot water systems and 2041 for supplementary insulation (http://palyazatok.org/klimabarat-otthon-energiahatekonysagi-alprogram-nyertes-palyazatok/). Solar cells are sold by specialized companies that are not active in more conventional fields, so personal experience or building on other people's experience cannot be used as riskcontrolling methods. Most of the specialized companies are newly established, and the brands sold are also new so consumers cannot be sure about their future presence on the market. Companies use the origin of the product (mainly Germany) as their major selling point. Endorsement activity is rare.

Most of these problems are temporary and will diminish as the market matures: New companies will stay on the market for longer time, more conventional companies will also 
enter the market, government will help with purchases, laboratory testing, or grants, and there will be a higher level of market penetration. Thus, the level of risk is not solely a characteristic of the technology itself, but also of the market.

Figure 7 illustrates that in the case of wall insulation, two barriers are most urgent to overcome: The private cost-based payback period seems to be too long for mass-market consumers, and counter-interested market players seem to set back successful market penetration. The preventing power of the first factor can be reduced by subsidies. In order to battle the negative impact of counter-interested parties, different priorities should be set and pushed through in state policy.

Photovoltaic cells fall into the prohibitive category for mass-market penetration regarding (almost) every barrier factor, but pushing and pulling the profile gives some space for improved promotion (e.g., by lowering the compromise, building strategic alliances, providing information, and using more effective marketing tools).

The effectiveness of the National Energy Saving Programme could be significantly increased in 2010 and later if the budget for support was concentrated on "yellow zone" options, promising high GHG mitigation potential (e.g., insulation of walls), as this would be the way to achieve the highest energy saving results with the least costs.

Higher market penetration of "green zone" option should not be promoted by subsidies. As those options pay back also to the individual, other measures would be more effective, such as making credit and loan opportunities easier available, providing information, making widespread use of marketing tools, product standards, or labelling. However, it should be noticed that consumers tend not to replace household items (e.g., light bulbs and washing machines) until they become unusable, which makes the penetration of even "green zone" options rather slow. The method of profiling may provide significant help in identifying the non-financial barriers of "green zone" options.

\section{Conclusions}

Intergovernmental Panel on Climate Change is pressing for urgent steps in order to keep climate change within $2^{\circ} \mathrm{C}$. Achieving this goal requires sacrifices, but it is not clear how big this sacrifice should be and will be. Political support, as well as understanding and agreement in society, will most likely be higher for a programme which implements GHG emission abatement with low social costs. For designing such programmes, methods of economics and other disciplines should be utilized to ensure cost-efficient implementation of climate change strategy.

This article presented the use of three interrelated tools - construction of the marginal social cost curve, identification of three zones of action, as well as profiling the implementation barriers of selected options - which can help design GHG-related consumer policy to increase its efficiency. We argue that options with high environmental potential and negative, zero, or slightly positive social costs should be spotlighted. These are the typical "yellow" and "green zone" options that are most likely to be implemented, though some barriers may discourage and slow down the process. Consumer policy should use the profile of these options and work towards overcoming implementation barriers.

In the case study, we evaluated the Hungarian GHG-related consumer policy from 1999 until now. The energy saving focus of the policy reflects a strong efficiency orientation, which has its limits regarding sustainability. The exclusive or overemphasized use of the efficiency-based approach in GHG-related consumer policy threatens to downplay the rebound-effect and distracts the attention from the need for significant behavioural change. 
However, the positive environmental impact can be substantial if a broad sector of the society is reached, which means that consumer policy should focus on solutions rather than products in the future. Also, more attention has to be paid to uninterested consumers who represent the majority of the market. Co-benefits need to be emphasized more strongly during the implementation phase, and positioning of the consumer policy does not necessarily have to be "green." Health benefits of products, energy saving potential, cost savings and payback, or high prestige might be more effective selling points of environmental policy in certain cases. Building coalitions with economic agents interested in implementing environmental options as well as cooperating with other sector policies are crucial for reducing costs and addressing implementation barriers. Last but not least, using different communication tools for the same programme in order to target different consumer segments may result in higher effectiveness and a wider scope of consumer policy - as the case study in this article suggests. Profiling shows the critical points where the profile string can be pushed or pulled by properly defined consumer policy in order to "move" the analysed GHG mitigation option into the "acceptable" or contingent category.

A challenge for further research is to analyse how different consumer policy tools can be applied for specific GHG mitigation options belonging to the "green," "yellow," or even "red zone" and how exactly the existing barriers to implementation can be cut back in order to reach as many consumers as possible with differentiated positioning on the market.

Acknowledgement Our research activity has been supported by the Norwegian Financial Mechanism.

\section{References}

Ajzen, I. (1985). From intentions to actions: A theory of planned behavior. In J. Kuhl \& J. Beckman (Eds.), Action control: From cognition to behavior (pp. 11-39). Heidelberg: Springer.

Akaah, I. P., \& Korgaonkar, P. K. (1988). A conjoint investigation of the relative importance of risk relievers in direct marketing. Journal of Advertising Research, 28(4), 38-44.

Arbuthnott, K. D. (2009). Education for sustainable development beyond attitude change. International Journal of Sustainability in Higher Education, 10, 152-163.

Baden, S., Fairey, P., Waide, P., de T'serclaes, P., \& Lautsen, J. (2006). Hurdling financial barriers to low energy buildings: Experiences from the USA and Europe on financial incentives and monetizing building energy savings in private investment decisions. Proceedings of 2006 ACEEE Summer Study of Energy Efficiency in Buildings. Washington: American Council for an Energy Efficient Economy.

Behr, R. L., \& Iyengar, S. (1985). Television news, real world cues, and changes in the public agenda. Public Opinion Quarterly, 49, 38-57.

Bertoldi, P., \& Bogdan, A. (2006a). Residential lighting consumption and saving potential in the enlarged $E U$. European Commission Directorate-General Joint Research Centre Institute for Environment and Sustainability.

Bertoldi, P., \& Bogdan, A. (2006b). Electricity consumption and efficiency trends in the enlarged European Union-Status report 2006. European Commission Directorate-General Joint Research Centre Institute for Environment and Sustainability.

Bonaiuto, M., Breakwell, G. M., \& Cano, I. (1996). Identity processes and environmental threat: The effects of nationalism and local identity upon perception of beach pollution. Journal of Community and Applied Social Psychology, 6, 157-175.

Burgess, J., Bedford, T., Hobson, G., Davies, G., \& Harrison, C. M. (2003). (Un)sustainable consumption. In F. Berkhout, M. Leach, \& I. Scoones (Eds.), Negotiating environmental change: New perspectives from social science (pp. 261-293). Cheltenham: Edward Elgar Publishing Ltd.

CEN Technical Committee 250 (2010). Eurocodes. http://eurocodes.jrc.ec.europa.eu/. 
Crane, A., \& Peattie, K. (1999). Has green marketing failed...or has it never really tried? Conference Proceedings of the 1999 Business Strategy and the Environment Conference, 16th-17th September. Leeds, UK: University of Leeds.

Creyts, Y., Derkach, A., Nyquist, S., Ostrowski, K., \& Stephenson, J. (2007). U.S. greenhouse gas abatement mapping initiative. Washington, DC: McKinsey \& Company.

Csutora, M., \& Zilahy, G. (1998). Economic analysis of greenhouse gas mitigation options in Hungary. Ph.D. Conference. Budapest: Budapest University of Economic Sciences.

Davies, J., Foxall, G. R., \& Pallister, J. (2002). Beyond the intention-behaviour mythology: An integrated model of recycling. Marketing theory, 2, 29-113.

Dowling, G. R., \& Staelin, R. (1994). A model of perceived risk and intended risk-handling activity. Journal of Consumer Research, 21, 119-134.

Ellen, P. S., Wiener, J. L., \& Cobb-Walgren, C. (1991). The role of perceived consumer effectiveness in motivating environmentally conscious behaviors. Journal of Public Policy \& Marketing, 10, 102-117.

European Commission. (2005). Attitudes of European citizens towards the environment, Special Eurobarometer 217. Brussels: European Commission.

European Commission. (2008). Attitudes of European citizens towards the environment, Special Eurobarometer 295. Brussels: European Commission.

European Commission. (2009). Energy policy factsheets for countries. Available at: http://ec.europa.eu/ energy/energy_policy/doc/factsheets/country/hu/mix_hu_hu.pdf.

European Commission Joint Research Centre. (2009). PV status report: Research, solar cell production and market implementation of photovoltaics. Available at: http://re.jrc.ec.europa.eu/refsys/pdf/PV-Report2009.pdf.

Featherman, M. S., \& Pavlou, P. A. (2003). Predicting e-services adoption: A perceived risk facets perspective. International Journal of Human Computer Studies, 59, 451-474.

Fliegenschnee, M., \& Schelakovsky, M. (1998). Umweltpsychologie und Umweltbildung: Einführung aus humanökologischer Sicht. Wien: Facultas Universitäts Verlag.

GAP (Global Action Plan). (2008). EcoTeams evaluation report. Available at: http://www.globalactionplan. org.uk/upload/resource/GAP\%20EcoTeams\%20Evaluation\%20Report\%20June\%2020081.pdf.

Government Decree of 1107/1999 (08.10) of the Hungarian Government. (1999). Magyar Közlöny 99/89, Budapest.

Hines, J. M., Hungerford, H. M., \& Tomera, A. N. (1986). Analysis and synthesis of research on responsible pro-environmental behavior: A meta-analysis. The Journal of Environmental Education, 18(2), 1-8.

Hinostroza, M., Cheng, C., Zhu, X., Fenhann, J., Figueres, C., \& Avendano, F. (2007). Potentials and barriers for end-use energy efficiency under programmatic CDM. Working Paper No. 3, CD4CDM Working Paper Series. Roskilde: UNEP Risø Centre on Energy, Climate and Sustainable Development. Available at: http://www.cd4cdm.org/Publications/pCDM\&EE.pdf.

Hockerts, K., \& Wüstenhagen, R. (2009). Greening Goliaths versus emerging Davids - Theorizing about the role of incumbents and new entrants in sustainable entrepreneurship. CBS Working Paper Series. CBS Center for Corporate Social Responsibility. Available at: http://openarchive.cbs.dk/bitstream/handle/ 10398/7122/wp\%20cbscsr\%202009-1.pdf?sequence=3.

Hofmeister-Tóth, Á., Kelemen, K., \& Piskóti M. (2010). Changes in consumer behavior patterns in the light of sustainability. Conference Proceedings of Business and Economics Society International 2009 Conference, 15-19 July, Athen, pp 51-61.

IPCC. (1997). Workshop on mitigation and adaptation cost assessment. Denmark: IPCC.

Jaeger, C., Dürrenberger, G., Kastenholz, H., \& Truffer, B. (1993). Determinants of environmental action with regard to climate change. Climate Change, 23, 193-211.

Jakob, M. (2006). Marginal costs and co-benefits of energy efficiency investments. The case of the Swiss residential sector. Energy Policy, 34, 172-187.

Jakob, M. (2007). The drivers of and barriers to energy efficiency in renovation decisions of single-family homeowners. CEPE Working Paper Series 07-56. Zürich: CEPE Center for Energy Policy and Economics, ETH.

Kollmuss, A., \& Agyeman, J. (2002). Mind the gap: Why do people act environmentally and what are the barriers to pro-environmental behaviour? Environmental Education Research, 8, 239-260.

$\mathrm{KSH}$. (2005). Housing conditions at the turn of the century. Budapest: KSH.

Labouze, E., Monier, V., Le Guern, Y., \& Puyou, B. (2003). Study on environmental effects related to the lifecycle of products and services. Final Report version 2. Paris, France: European Commission, Directorate General Environment, Directorate A-Sustainable Development and Policy Support, BIO Intelligence Service/O2 France.

Marjainé Szerényi, Z., Zsóka, Á., \& Széchy, A. (2009). Environmental education and pro-environmental consumer behaviour-Results of a university survey. Joint Actions on Climate Change Conference, 8-10 June, 2009, Aalborg, Denmark. Available at: http:/gin.confex.com/gin/2009/webprogram/Paper2619.html.

Mishan, E. J., \& Quah, E. (2007). Cost benefit analysis (5th ed.). London: Routledge. 
Moll, H. C., Noorma, K., Kok, R., Engström, R., Throne-Holst, H., \& Clark, C. (2006). Pursuing more sustainable consumption by analysing household metabolism in European countries and cities. In T. Jackson (Ed.), The Earthscan reader in sustainable consumption (pp. 67-87). UK: Earthscan.

Nässén, J., \& Holmberg, J. (2009). Quantifying the rebound effects of energy efficiency improvements and energy conserving behaviour in Sweden. Energy Efficiency, 2, 221-231.

Nemcsicsné Zsóka, Á. (2005). Consistency and gaps in pro-environmental organisational behaviour. Ph.D. dissertation. Budapest: Corvinus University of Budapest.

NEP. (2009). National Energy Saving Programme. Available in Hungarian at: http://eupalyazatiportal.hu/ nemzeti_energiatakarekossagi_program_2009/.

Novikova, A., \& Ürge-Vorsatz, D. (2007). Carbon dioxide mitigation potential in the Hungarian residential sector. Report on behalf of the Ministry of Environment and Water of the Republic of Hungary. Available at: http:// 3csep.ceu.hu/projects/carbon-dioxide-mitigation-potential-in-the-hungarian-residential-sector.

Paavola, J. (2007). Institutions and environmental governance: A reconceptualization. Ecological Economics, $63,93-103$.

Peattie, K. (1999). In M. Charter \& M. Polonsky (Eds.), Rethinking marketing: Shifting to a greener paradigm. In: Greener marketing. Sheffield: Greenleaf Publishing Ltd.

Reinhard, H., \& Biermayr, P. (2000). The rebound effect for space heating. Empirical evidence from Austria. Energy Policy, 38, 403-410.

Robins, N., \& Roberts, S. (2006). Making sense of sustainable consumption. In T. Jackson (Ed.), The Earthscan reader in sustainable consumption (pp. 39-50). UK: Earthscan.

Roselius, T. (1971). Consumer rankings of risk reduction methods. Journal of Marketing, 35(1), 56-61.

Rubik, F., Scholl, G., Biedenkopf, K., Kalimo, H., Mohaupt, F., Söebech, Ó., et al. (2009). Innovative approaches in European sustainable consumption policies. Berlin: Schriftenreihe des IÖW 192/09.

Shove, E. (2003). Comfort, cleanliness and convenience: The social organization of normality. Oxford: Berg Publisher.

Shove, E., Watson, M., Hand, M., \& Ingram, J. (2007). The design of everyday life, cultures of consumption series. USA: Berg Publishers.

Slovic, P. (1987). Perception of risk. Science, 236, 280-285.

Slovic, P., \& Weber, E. U. (2002). Perception of risk posed by extreme events. The Conference on Risk Management Strategies in an Uncertain World, held in 12-13 April, 2002, Palisades, New York, pp 1-21.

Southerton, D., Chappells, H., \& Van Vliet, B. (Eds.). (2004). Sustainable consumption: The implications of changing infrastructures of provision. Cheltenham: Edward Elgar.

Spaargaren, G. (2000). Lifestyles, consumption and the environment: The ecological modernisation of domestic consumption. In A. P. J. Mol \& D. A. Sonnenfeld (Eds.), Ecological modernisation around the world: Perspectives and critical debates. London: Frank Cass.

Spaargaren, G. (2003). Sustainable consumption: A theoretical and environmental policy perspective. Society \& Natural Resources, 16, 687-701.

Spaargaren, G., \& Martens, S. (2005). Globalisation and the role of citizen-consumers in environmental politics. In F. Vijen, K. Zooteman, \& J. Pieters (Eds.), A handbook of globalisation and environmental policy: National government interventions in a global arena. Cheltenham: Edward Elgar.

Stern, P. C. (2000). Toward a coherent theory of environmentally significant behaviour. Journal of Social Issues, 56, 407-424.

Stern, N. (2008). The economics of climate change. The American Economic Review, 98, 1-37.

Thøgersen, J. (2005). How may consumer policy empower consumers for sustainable lifestyles? Journal of Consumer Policy, 28, 143-178.

Thøgersen, J., \& Crompton, T. (2009). Simple and painless? The limitations of spillover in environmental campaigning. Journal of Consumer Policy, 32, 141-163.

Tukker, A., \& Jansen, B. (2006). Environmental impacts of products. A detailed review of studies. Journal of Industrial Ecology, 10(3), 159-182.

Ürge-Vorsatz, D., \& Füle, M. (1999). Economics of greenhouse gas limitations. Hungary Country Study. Denmark: UNEP Collaborating Centre on Energy and Environment and Riso National Laboratory.

van Raaij, W., \& Verhallen, T. (1983). A behavioral model of residential energy use. Journal of Economic Psychology, 3(1), 39-63.

Weidema, B. P., Suh, S., \& Notten, P. (2006). Setting priorities within product-oriented environmental policy: The Danish perspectives. Journal of Industrial Ecology, 10, 73-87.

Wesselink, B., \& Deng, I. (2009). Sectoral emission reduction potentials and economic costs for climate change. London: ECOFYS.

Widegren, O. (1998). The new environmental paradigm and personal norms. Environment and Behavior, 30, 75-101.

World Research Institute (2010). Global climate trends 2005. Available at: http://earthtrends.wri.org/ pdf_library/data_tables/cli5_2005.pdf. 
Wüstenhagen, R. (1998). Greening Goliaths vs. multiplying Davids, Pfade einer Coevolution ökologischer Massenmärkte und nachhaltiger Nischen. St. Gallen: IWÖ-HSG.

Zilahy, G. (2004). Organisational factors determining the implementation of cleaner production measures in the corporate sector. Journal of Cleaner Production, 12(4), 311-319.

Zilahy, G., Nemcsicsné Zsóka, Á., Szeszler, Á., Ürge-Vorsatz, D., Markandya, A., \& Hunt, A. (2000). The indirect costs and benefits of greenhouse gas limitation: Hungary case study. Handbook Reports. Denmark: UNEP Collaborating Centre on Energy and Environment and Riso National Laboratory. 